\title{
A Paixão dos Amantes: Separação e Superação em “Os Sapatinhos Vermelhos" e "Sem Ana, Blues”, de Caio Fernando Abreu
}

Thais Torres de Souza ${ }^{1}$

\section{RESUMO}

O artigo tem o objetivo de analisar dois contos do livro Os dragões não conhecem o Paraíso, de Caio Fernando Abreu que apresentam a temática da separação dos amantes: "Os Sapatinhos Vermelhos" e "Sem Ana, Blues". Abandonadas, as personagens buscam superar a separação e, com isso, reconstituírem-se como sujeitos. Aparentemente, há diferenças entre a vingança realizada pela personagem de "Os Sapatinhos Vermelhos" e o modo como o narrador de "Sem Ana, Blues" se esquece daquela que o abandonou. No entanto, tendo como base o texto "Luto e Melancolia" de Freud e o livro A Separação dos Amantes, de Caruso, é possível observar também na atitude de extrema devoção do personagem de "Sem Ana, Blues" uma tentativa de realizar uma vingança e, com ela, tentar superar o abandono. Os contos sugerem que a concepção que Abreu apresenta do erotismo nesse livro está fundamentada, sobretudo, no fato da sexualidade sustentar-se no conflito, tendo como consequência a eterna insatisfação dos amantes. Esse modo de compreender o conceito de erotismo encontra ecos no pensamento de Bataille, para quem a sexualidade só pode se concretizar através da ruptura entre os amantes na busca pela realização de seus desejos.

PALAVRAS-CHAVE: Caio Fernando Abreu, psicanálise, literatura, erotismo.

\section{ABSTRACT}

The objective of this paper is to analyze two novels presented in the book entitled Os dragões não conhecem o Paraíso, written by Caio Fernando Abreu. These novels - "Os Sapatinhos Vermelhos" and "Sem Ana, Blues" - address the separation of the lovers. Once abandoned, the characters long to overcome their apartness condition and, then, reconstitute themselves as subjects. Aparently, the revenge taken by the character from "Os Sapatinhos Vermelhos" and the way the narrator of "Sem Ana, Blues" forgets who has abandoned him are different. However, based on Freud's article "Mourning and Melancholia" and Caruso's book "Love and Separation", it's possible to identify, also through the attitude of extreme devotion of the character from "Sem Ana, Blues", an attempt to take revenge and then overcome the abandonment. These two novels prove that the concept of erotism presented by Abreu in this book is founded, above all, on the fact that sexuality sustains itself on conflict, what causes the infinite lovers dissatisfaction. This comprehension of the concept of erotism echoes Bataille's thought, according to which sexuality can only be effective through the rupture between the lovers in their quest for the realization of their desire.

KEYWORDS: Caio Fernando Abreu, psychoanalysis, literature, erotism.

Os Dragões não conhecem o paraíso é um livro de contos de Caio Fernando Abreu publicado em 1988, cuja temática principal é o amor e o erotismo. O próprio autor afirma isso na apresentação que abre o livro:

Se o leitor quiser, este pode ser um livro de contos. Um livro com 13 histórias independentes, girando sempre em torno do mesmo tema: amor. Amor e sexo, amor e morte, amor e abandono, amor e alegria, amor e memória, amor e medo, amor e loucura (ABREU, 1988, p.4).

1 Doutoranda em Literatura Brasileira pela Universidade de São Paulo. Professora do IFSP. Email: thaisiel@yahoo.com.br 
Nos treze contos que compõem o livro há uma vasta gama de personagens em busca da realização plena do erotismo: mulheres de meia-idade, adolescentes em processo de crescimento, homossexuais, bêbados, rejeitados, desiludidos vivenciam experiências como a separação, a descoberta da sexualidade, a solidão, o abandono. Vivem em busca da satisfação erótica, mas fazem isso em um mundo que nem sempre aprova e possibilita a concretude desses desejos.

Ainda que o amor seja o tema central dessas "13 histórias independentes", ele não leva a qualquer plenitude nesses textos, mas se realiza na constante tensão entre aquilo que as personagens desejam - e raramente alcançam - e as decepções que o princípio da realidade lhes impõe. Se o livro pode ser considerado "um romance desmontável, onde essas 13 peças possam completar-se, esclarecer-se, ampliar-se [...] para formar uma espécie de todo" (ABREU, 1988, p.4), como o autor afirma na apresentação, o mesmo não pode ser dito sobre as personagens. A incompletude, a falta de qualquer esclarecimento sobre si mesmas ou dos parceiros com quem tentam se envolver é evidente e elas não formam, de maneira alguma, "uma espécie de todo".

Em "Os Sapatinhos Vermelhos" e "Sem Ana, Blues" as personagens são abandonadas de forma direta e, aparentemente, sem retorno, após viverem longos relacionamentos. Os textos giram em torno do processo de superação pelo qual as personagens passam após a separação. Em "Sem Ana, Blues", os mecanismos mais diversos são utilizados para superar o trauma do abandono, desde a embriaguez, passando por uma reconstituição da auto-estima até a aparente completa desvinculação com a pessoa amada. Voltarei a esse conto mais adiante.

Para Freud (2002) e Melaine Klein (1996), há uma forte semelhança entre o processo de luto e o de superação após uma separação amorosa. Em ambos os casos, tentase superar a ausência de seres amados através de um longo e difícil processo. Assim Klein designa que ocorre a superação bem-sucedida:

Só gradualmente, retomando a confiança nos objetos externos e em valores de todos os tipos, é que a pessoa de luto consegue fortalecer mais uma vez sua confiança na pessoa amada que perdeu. Então ela pode admitir novamente que este objeto não era perfeito, sem perder a confiança e o amor que sente por ele, nem temer sua vingança. Quando se atinge esse estágio, já se fez um avanço importante no trabalho de luto em direção a sua recuperação (KLEIN, 1996, p.398).

Em "Os Sapatinhos Vermelhos", apenas um mecanismo é utilizado para superar o abandono: a vingança. A personagem principal Adelina calça um par de sapatos vermelhos, se arruma de forma sensual e entra em uma boate barata decidida a se relacionar sexualmente com os homens que encontrar por lá. Essa é uma maneira clara de atingir o examante, pois os sapatos foram um presente dele e serão um importante instrumento de sedução para um ato sexual profundamente contrastante com o relacionamento que tinha até então.

Os homens que conhece nesse lugar não são chamados pelo nome, que ela não consegue fixar ("Sergio ou Sílvio, qualquer coisa assim"; "Ricardo, Roberto, ou seria Rogério?"; ABREU, 1988, p.76), mas por apelidos criados a partir das características físicas, cuja sensualidade latente mais lhe chamou a atenção. "O negro", "o tenista dourado" e "o mais baixo" são escolhidos exatamente por serem o extremo oposto do ex-amante. Assim ela descreve esse último no momento do rompimento: 
Ele ficou então parado à frente dela, muito digno e tão comportadamente um senhor-de-família-da-Vila-Mariana dentro do terno suavemente cinza, gravata pouco mais clara, no tom exato das meias, sapatos ligeiramente mais escuros. Absolutamente controlado. Nem um fio de cabelo fora do lugar enquanto repetia pausado, didático, convincente - mas Adelina, você sabe tão bem quanto eu, talvez até melhor, a que ponto de desgaste nosso relacionamento chegou. Devia falar desse jeito mesmo com os alunos, é impossível que você não perceba como é doloroso para mim mesmo encarar este rompimento. Afinal, a afeição que nutro por você é um fato. Teria mesmo chegado ao ponto de dizer nutro? Teria, teria sim, teria dito nutro \& relacionamento \& rompimento \& afeto, teria dito também estima $\&$ consideração \& mais alto apreço e toda essa merda educada que as pessoas costumam dizer para colorir a indiferença quando o coração ficou inteiramente gelado (ABREU, 1988, p.70).

Se o amante ausente é um elegante "senhor-de-família-da-Vila-Mariana", o que chama a atenção nos três participantes da orgia é a sensualidade selvagem que eles exalam e o prazer que o corpo deles prenuncia. Eles assim são descritos pela primeira vez:

Eram três, estavam juntos, mas o negro foi o primeiro a pedir licença para sentar [...] Tinha traços finos, o negro, afilados como os de um branco, embora os lábios mais polpudos, meio molhados. Músculos que estalavam dentro da camiseta justa, dos jeans apertados. Leve cheiro de bicho limpo, bicho lavado, mas indisfarçavelmente bicho atrás do sabonete.

$$
[\ldots]
$$

Sorriu para o outro, encostado no balcão, o moço dourado com jeito de tenista. Não que fosse louro, mas tinha aquele dourado do pêssego quando mal começa a amadurecer espalhado na pele, nos cabelos, provavelmente nos olhos que ela não conseguia ver sem óculos.

$$
[\ldots]
$$

Tão escuro ali dentro que mal podia ver o outro, ao lado do tenista dourado. Um pouco mais baixo, talvez. Mas os ombros largos. Qualquer coisa no porte, embora virado de costas para ela, de frente para o balcão, curvado sobre o copo de bebida, qualquer coisa na bunda firme desenhada pelo pano da calça - qualquer coisa ali prometia (ABREU, 1988, p.73, grifos meus).

O ex-amante utilizou palavras frias e antiquadas para explicar o "afeto" e o "mais alto apreço" - nunca o desejo - que sentia por Adelina. Já esses três homens utilizavam poucas palavras (rosnadas muitas vezes) e muitas ações, para demonstrar que a desejavam:

Então dançaram, um de cada vez. O negro apoiou a mão pesada na cintura dela e, puxando-a para si, encaixou o ventre dos dois, quase como se a penetrasse assim [...] puxada pela mão do tenista-dourado. Que a fez encostar a cabeça entre os dois peitos dele, cheiro de colônia, desodorante, suor limpo de homem embaixo da camisa pólo amarelinha, lambeu a orelha dela, mordiscou a curva do pescoço [...] O mais baixo não quis dançar. Quero foder você, rosnou: pra que essa frescura toda? (ABREU, 1988, p.76). 
Procurar outros amantes é, por um lado, uma forma de realizar aquilo que Igor Caruso (1989) em A Separação dos Amantes chama de "a fuga para adiante", uma forma de esquecer a pessoa amada, procurando novos relacionamentos. No entanto, o objetivo não é seguir com sua vida com esses novos parceiros, mas matar o objeto de amor que não está mais lá, vingando-se dele e, com isso, superar a separação. A personagem parece escolher a maneira mais eficiente de operar isso, primeiro ao fazer questão de escolher homens completamente diferentes do antigo amante, depois, ao optar por não tirar dos pés em nenhum momento os sapatos vermelhos que ganhou de presente, transformando, com isso, o amante em um expectador indireto da orgia, através dos sapatos que foram dados por ele a Adelina.

A agressividade é, segundo Igor Caruso, o primeiro mecanismo de defesa utilizado pelos amantes que se separam. Isso dá origem à "desvalorização do ausente", quando aquele que foi abandonado tende a desprezar e recusar todas as características da pessoa que o abandonou:

Mesmo que a consciência registrasse aspectos negativos no companheiro, o certo é que ele correspondia a fortes expectativas do ideal do Ego. Agora, sua imagem deve ser desvalorizada para que o Ego, profundamente ferido, possa se reconciliar com um ideal do Ego abalado e tenha condições de continuar vivendo [...] trata-se da forma mais segura de tornar definitiva a morte do ausente na consciência e de torná-la aceitável para o Ego (CARUSO, 1989, p.26).

É preciso matar o amante dentro de si mesma para superar o abandono. Para Caruso (1989), embora essa seja a única alternativa para se reconstituir como sujeito, tratase de uma experiência profundamente dolorosa, pois permite vivenciar a morte ainda em vida. O autor afirma que "a separação é um problema de morte entre os vivos" e é uma "sentença de morte recíproca":

Na medida em que a condenação se cumpre na própria consciência e na consciência do outro, a sentença de morte do outro significa decretar a morte de si próprio. O Outro morre em vida, mas morre dentro de mim [...] A sentença foi igualmente pronunciada em relação a mim: eu também morro na consciência do outro [...] Apesar de que eu ainda vivo em meu corpo, sou um cadáver no outro (CARUSO, 1989, p.20).

No exato momento em que abre a caixa de sapatos após a separação, Adelina parece matar a mulher que tinha se relacionado com aquele "senhor-de-família-da-VilaMariana" até então, matando-o também dentro de si mesma. Ao calçá-los e relacionar-se sexualmente com esses homens, ela mata tanto o sedutor quanto o seduzido, pois se vinga daquele que a abandonou e deixa de ser a Adelina que foi abandonada:

E eram lindos, mais lindos do que podia lembrar. Mais lindos do que tinha tentado se expressar quando protestou, comedida e comovida - mas são tão... tão ousados meu bem, não têm nada a ver comigo. Que evitava cores, saltos, pinturas, decotes, dourados ou qualquer outro detalhe capaz sequer de sugerir sua secreta identidade de mulher-solteira-eindependente-que-tem-um-amante-casado (ABREU, 1988, p.72). 
No momento em que calça os sapatos, ela abandona sua identidade de mulher discreta e sóbria, amante de um homem casado, para se tornar Gilda, nome com o qual se apresenta para os três participantes da orgia. A referência à personagem de Rita Hayworth no filme Gilda, dirigido por Charles Vidor em 1946, é clara. Gilda é a mulher sedutora e fatal que Adelina gostaria de se tornar, embora não soubesse muito bem o que essa identidade representava:

[...] falava como a dublagem de um filme. Uma mulher movia o corpo e a boca: ela falava. Um filme preto e branco, bem contrastado, um filme que não tinha visto, embora conhecesse bem a história. Porque alguém contara, em hora de cafezinho, porque vira os cartazes ou lera qualquer coisa numa daquelas revistas femininas que tinha aos montes em casa (ABREU, 1988, p.75).

Os sapatos vermelhos promovem essa transformação. Adelina quer se transformar em Gilda, ainda que de forma artificial e sem saber exatamente o que significa ser essa personagem, quer deixar de ser a amante de meia-idade, abandonada e seduzida para se tornar uma sedutora mulher madura, devoradora de homens ${ }^{2}$. Para isso, ela calça os sapatos "vermelhos - mais que vermelhos: rubros, escarlates, sanguíneos -, com saltos altíssimos, uma pulseira estreita na altura do tornozelo" (ABREU, 1988, p.72).

O negro, o tenista-dourado e o mais baixo também se sentem seduzidos pelos sapatos e imploram para que ela não os tirasse durante o ato sexual. Trata-se, evidentemente, de um fetiche. Para Freud, o fetichismo ocorre quando um objeto inanimado não apropriado para fins sexuais substitui o órgão sexual. Ele ainda ressalta que os sapatos ou os chinelos são símbolos da genitália feminina:

[...] o pé substitui o pênis da mulher, cuja ausência é profundamente sentida. Em muitos casos de fetichismo dos pés pode-se demonstrar-se que a pulsão de ver [escopofílica], originalmente voltada para os genitais e querendo chegar a seu objeto de baixo para cima, foi detida em seu trajeto pela proibição e pelo recalcamento, e por isso reteve como fetiches os pés ou os sapatos (FREUD, 2002, p.33).

Por um lado, através dos sapatos, os participantes da orgia acessariam indiretamente a genitália de Adelina-Gilda. Além disso, são os testemunhos de sua vingança, pois o presente do amante que a abandonou é utilizado em uma noite que ele reprovaria completamente, tendo em vista o modo recatado e contido como ele se comportava. Mas a principal função desses sapatos vermelhos no conto parece ser o modo como eles permitem que Adelina saia de sua posição de seduzida e abandonada para se tornar protagonista da sedução, numa tentativa de retomar o pênis que não possui, mas do qual sente falta. Essa é a função mais evidente desses sapatos que, adquirem a mágica função de transformar a personagem em um outro, matando aquela mulher que ela era até então. Ser outra pessoa parece ser a única maneira de não mais ser abandonada.

A epígrafe e o título do conto remetem diretamente ao conto de fadas "Os Sapatinhos Vermelhos", de Andersen. Nele, uma menina pobre é proibida pela senhora rica

\footnotetext{
${ }^{2}$ Essa personagem, a mulher de 40 anos sedutora e devoradora de homens é cara a Caio Fernando Abreu. Aparece também em "Dama da Noite", outro conto de Os dragões não conhecem o Paraíso e em Onde andará Dulce Veiga?, romance de 1990.
} 
que a acolhe de usar seus antigos sapatos vermelhos, que tinham sido feitos pela garota. Ela não deveria mais utilizá-los, porque essa cor era inadequada para ela. A menina insiste e, por esse motivo é condenada a dançar eternamente com os sapatos, batendo de porta em porta. As pessoas que a atendessem temeriam que o destino da menina se abatesse sobre eles e ela sofreria para sempre. Na versão de Andersen, ela é salva quando cortam seus pés, mas permanece aleijada, como punição pela desobediência ${ }^{3}$.

Em primeiro lugar, usar a cor vermelha era uma ousadia, pois a cor era destinada apenas aos nobres, o que não era o caso da menina do conto de fadas. Mas o vermelho também é o símbolo do desejo, segundo Bruno Bettelheim em A Psicanálise dos contos de fadas (1980). A obra foi uma importante referência para Marilena Chauí, no livro Repressão Sexual, publicado quatro anos antes de Os dragões não conhecem o paraíso. Segundo Callegari, biógrafa de Caio Fernando Abreu, a obra foi lida atentamente pelo escritor gaúcho. De fato, diversos elementos dessas histórias infantis são retomados nesse texto, como procurarei mostrar aqui.

Assim como nas histórias infantis, há a presença de um objeto mágico capaz de promover uma profunda mudança na personagem. Não por acaso, esses sapatos são vermelhos. É essa a cor do capuz de Chapeuzinho Vermelho e da maçã que enfeitiça a Branca de Neve, apenas para citar alguns dos exemplos. É a cor que torna a maçã envenenada ainda mais sedutora e que chama a atenção do lobo para a menina que ele deseja devorar. Chauí (1984, p.52) lembra que a cor remete a uma simbologia medieval, pois as bruxas fabricavam filtros de amor usando esperma e sangue menstrual. É, portanto, símbolo do perigo da sedução feminina.

A descrição dos sapatos da infortunada menina do conto de fadas destaca a cor que eles apresentam como principal motivo para que ela não pudesse mais utilizá-los:

No dia seguinte, os membros da congregação ficaram alvoroçados com os sapatos da menina. Os sapatos brilhavam como maçãs polidas, como corações, como ameixas tingidas de vermelho. Todos olhavam carrancudos. Até os ícones na parede, até as estátuas não tiravam os olhares reprovadores dos sapatos. A menina, no entanto, gostava cada vez mais deles (grifo meu)

Não basta afirmar que eles são vermelhos. Eles são mais que isso, possuem um vermelho reluzente, lembrando ameixas, maçãs e corações. A cor, quando utilizada para descrever esses frutos suculentos, parece ser um atrativo para que eles sejam devorados. É a mesma cor do coração, órgão responsável por bombear o sangue, igualmente rubro, centro simbólico das emoções humanas e vital para a sobrevivência. A comparação com esses elementos deixa claro que havia motivos suficientes para que esses sapatos fossem proibidos, visto que eles remeteriam ao perigo da sedução e da morte.

Os sapatos de Adelina também são vermelhos, "mais que vermelhos: rubros, escarlates, sanguíneos", como afirma o narrador. Representam uma sensualidade em estado bruto, sem as palavras e atitudes sensatas, corretas e educadas do amante que a abandonou e sem os entraves do superego. Ao usá-los, Adelina se transforma em uma mulher fatal, sedutora, desejada por homens brutos, tal qual é o seu desejo.

\footnotetext{
3 A versão do conto de Andersen utilizada foi encontrada no site: http://recantodasletras.uol.com.br/ contosdefantasia/697486. Acesso em janeiro de 2009.
} 
Ao analisar a famosa história da Borralheira (ou Cinderela), Bettelheim apresenta diversos contos de fadas em que o ato de calçar um sapato ou colocar um anel na mão de uma mulher representam a aceitação do ato sexual tanto por parte do homem, como pela mulher. Para que essa aceitação ocorra, é preciso que o sapato e o anel caibam perfeitamente no corpo feminino:

Um receptáculo pequenino dentro do qual se pode inserir uma parte do corpo de modo justo pode ser visto como um símbolo da vagina. Algo que é frágil e não deve se esticar porque romperia lembra-nos o hímen; e algo que se pode perder com facilidade no final de um baile quando o amado tenta estreitar a amada, parece uma imagem apropriada à virgindade (BETTELHEIM, 1980, p.304).

Nas diversas versões do conto, o príncipe descobre que a Borralheira é a noiva certa para ele porque os sapatos cabem perfeitamente nos seus pés, diferentemente do que acontece com as irmãs dela, que mutilam os pés ${ }^{4}$ para que eles caibam nos sapatos perdidos. O sangue que escorre dos sapatos daquelas que simulam ser as donas dos sapatos perdidos indica que elas não são tão virgens quanto Borralheira que "não sangra em nenhuma parte do corpo", segundo Bettelheim. Seu comportamento no ato da sedução também dá ao príncipe a segurança de que ele necessita na escolha de seu objeto de desejo.

Sua fuga repetida mostra que, ao contrário das irmãs, ela não é agressiva na sexualidade e espera pacientemente ser escolhida. Mas uma vez escolhida, não reluta. Quando coloca o sapatinho, em vez de esperar que o príncipe o faça, mostra sua capacidade de organizar o próprio destino. 0 príncipe sentia muita ansiedade a respeito das irmãs, tanto que não podia ver o que se passava ${ }^{5}$. Mas sente-se muito seguro com Borralheira. Uma vez que ela Ihe dá essa segurança, é a noiva certa para ele (BETTELHEIM, 1980, p.310).

O comportamento de Borralheira é oposto ao de Adelina e ao da menina de "Sapatinhos Vermelhos". Enquanto a última é duramente punida, não por calçar, mas por recusar-se a descalçar seus sapatos vermelhos - recusando, talvez, conter seus impulsos sexuais - Adelina coloca os sapatos, assumindo a posição ativa no ato da sedução e nisso constitui sua vingança. Além disso, os sapatos de ambas são vermelhos, deixando claro que elas não são puras como a Borralheira, cujos sapatos são de cristal, mas ao contrário, exibem sua sensualidade e seu posicionamento ativo no ato da sedução.

Os sapatos, símbolos da vagina para Bettelheim, símbolo do pênis ausente na mulher para Freud, possuem nesses dois contos a cor do desejo, do pecado, assegurando aos homens o poder de sedução feminino. Para a menina do conto de fadas, usar esses sapatos é um ato passível de dura punição. Para Adelina, personagem do conto de Caio Fernando Abreu, assegura a eficiência de sua vingança.

\footnotetext{
${ }^{4}$ Em algumas versões do conto, as irmãs de Borralheira cortam os calcanhares ou os dedos dos pés para que eles caibam no sapato.

${ }^{5}$ Ele precisa ser alertado por outros de que havia sangue nos sapatos, o que significava que elas haviam mutilado os pés para que eles coubessem neles.
} 
A posição ativa da personagem em seu processo de superação permite, a princípio, que o conto seja comparado com aquilo que Marilena Chauí chama de "contos de partida". Neles, "a sexualidade amadurecida e vencedora das fantasias persecutórias mais antigas aparece no próprio herói ou na heroína cujos objetos mágicos (oferecidos por um adulto) Ihe permitem, sozinhos, vencer a perseguição" (CHAUÍ, 1984, p.39).

Em "Os Sapatinhos Vermelhos", Adelina é abandonada numa data próxima da Páscoa. O dia escolhido para a orgia não poderia ser outro: é sexta-feira da Paixão. 0 sentido do feriado é alterado por ela, ao menos a princípio:

Bebeu outro gole [de whisky] um pouco sôfrega. Precisava apressar-se, antes que a quinta virasse Sexta-Feira Santa e os pecados começassem a pulular na memória feito macacos engaiolados: não beba, não cante, não fale nome feio, não use vermelho, o diabo está solto, leva sua alma para o inferno. Ela já está lá, no meio das chamas, pobre alminha, nem dez da noite, só filmes sacros na tevê, mantos sagrados, aquelas coisas, SextaFeira da Paixão e nem sexo, nem ao menos sexo, isso de meter, morder, gemer, gozar, dormir (ABREU, 1988, p.70).

A sedução inicia-se, no entanto, na quinta-feira. Os três homens seguem para o apartamento dela, passam o dia fazendo sexo com Adelina e vão embora na tarde de sextafeira. Ao final da jornada, ela parece ter conseguido seu intento: "e não era mais Gilda, nem Adelina nem nada. Era um corpo sem nome, varado de prazer, coberto de manchas de dentes e unhas, lanhado dos tocos das barbas amanhecidas, lambuzada do leite sem dono dos machos das ruas. Completamente satisfeita. E vingada" (ABREU, 1988, p.79).

Depois disso, Adelina consegue aquilo que até então tanto tinha desejado: o retorno do amante. Mas após os acontecimentos do dia anterior, isso não tem mais importância alguma:

Acordou no Sábado de Aleluia, manhã cedo, campainha furando a cabeça dolorida. Ele estava parado no corredor, dúzias de rosas vermelhas e um ovo de Páscoa nas mãos, sorriso nos lábios pálidos. Não era preciso dizer nada. Só sorrir também. Mas ela não sorria quando disse:

- Vá embora. Acabou.

Ele ainda tentou dizer alguma coisa, aquele ridículo terno cinza. Chegou mesmo a entrar um pouco na sala antes que ela o empurrasse aos gritos para fora, quase inteiramente nua, a não ser pelas meias de seda e os sapatos vermelhos de saltos altíssimos (ABREU, 1988, p.79).

Importante notar que os sapatos não estavam presentes apenas durante a sedução, mas ao longo de todo o processo da vingança, pois ela ainda os calçava no momento dessa tentativa de reconciliação. Só após o ex-amante ser rejeitado por ela e passar de sedutor a seduzido é que a vingança se completa. Ela pode, enfim, tirar os sapatos vermelhos e verificar o que ter estado com eles durante tanto tempo tinha lhe causado: "Só então ela sentou para tirar os sapatos. Na carne dos tornozelos inchados, as pulseiras tinham deixado lanhos fundos. Havia ferimentos espalhados sobre os dedos" (ABREU, 1988, p.79).

Importante notar que ao final desse processo, o resultado não é uma conciliação pacífica entre o antigo amor vivenciado e a necessidade de separar-se dele, mas um sofrimento, simbolizado pelos ferimentos que se espalhavam pelos dedos de Adelina. A 
personagem em nenhum momento vê o amante como um "objeto [que] não era perfeito, sem perder a confiança e o amor que sente por ele, nem temer sua vingança" (KLEIN, 1996, p.398). Ao contrário, a superação só ocorre diante do sofrimento do sedutor e do seduzido, que após a vingança trocam de papel.

Tudo acontece ao longo do feriado de Páscoa, celebração da paixão de Cristo feita pelos cristãos. O relato desse episódio na Bíblia começa com a glória vivida por Jesus no domingo de Ramos, quando ele é aclamado pelos fiéis na entrada de Jerusalém, poucos dias antes da traição de Judas; passa por seu sofrimento e crucificação e termina com a completa glória de Cristo, após a ressurreição. Já a paixão de Adelina segue um sentido oposto. O conto "Os Sapatinhos Vermelhos" se inicia com o relato do sofrimento vivido por Adelina após o abandono, passa por um breve momento de redenção - os prazeres da orgia com os três "machos vindos das ruas" que ela vivencia na sexta-feira -, para depois retornar ao sofrimento. É um trajeto oposto, ainda que em ambos os casos essas paixões relatem o percurso entre a redenção e o sofrimento, vivido em um período de cerca de sete dias ${ }^{6}$.

Adelina também vive uma aparente morte entre o prazer e o retorno ao sofrimento, tal como acontece com Jesus no relato bíblico. Ela toma "dois comprimidos para dormir o resto do sábado e o domingo de Páscoa inteiros" (ABREU, 1988, p.80). Ao acordar na segunda-feira, ela não encontra a glória vivida por Cristo no domingo de Páscoa, quando ele ressuscita após ter sido considerado derrotado pelos romanos. Ao contrário, Adelina retorna à solidão, à sua condição de mulher de meia-idade pouco sedutora e ao abandono que vivia antes daquela noite de sexta-feira de Páscoa. Percebe, então, que Adelina não morreu para dar lugar a Gilda:

Segunda-feira no escritório, quando a viram caminhando com dificuldade, cabelos presos, vestida de marrom, gola fechada, e quiseram saber o que era - um sapato novo, ela explicou muito simples, apertado demais, não é nada. Voltavam a doer, os ferimentos, quando ameaçava chuva (ABREU, 1988, p.80).

O sofrimento não é absoluto, pois a existência dos sapatos vermelhos permite que ela se transforme na Gilda e vivencie breves instantes de prazer:

ao abrir a terceira gaveta do armário para ver o papel de seda azul-clarinho guardando os sapatos, sentia um leve estremecimento. Tentava - tentava mesmo? - não ceder. Mas quase sempre o impulso de calçá-los era mais forte. Porque afinal, dizia-se, como num conto de Sonia Coutinho, há tantas sextas-feiras, tantos luminosos de néon, tantos rapazes solitários e gostosos perdidos nesta cidade suja... (ABREU, 1988, p.80).

A concepção de erotismo na obra de Caio Fernando Abreu se mantém aqui: o amor e a sexualidade são vividos no conflito, sempre de forma breve. Primeiro porque esses pequenos instantes de realização são efêmeros, ainda que a vingança se constitua de maneira plena. Mas, sobretudo, é o fato da morte espreitar momentos felizes que deixa

\footnotetext{
${ }^{6}$ Segundo a Bíblia, Cristo é recebido com honrarias em Jerusalém no domingo de Ramos. Na quinta-feira santa, realiza sua última ceia, é traído por Judas e capturado pelos romanos. Na sexta-feira, é crucificado e no domingo, ressuscita. No conto de Caio Fernando Abreu, Adelina é abandonada alguns dias antes da quinta-feira santa. O narrador não precisa quando, mas podemos supor que existiu um espaço de tempo entre o abandono e a decisão da personagem de calçar os sapatos vermelhos na noite da quinta-feira.
} 
clara a finitude e a incompletude do desejo. Adelina é uma mulher de meia-idade que sente no próprio corpo o prenúncio do envelhecimento e, consequentemente, da morte. Embora tenha vivido tais experiências calçando os sapatos vermelhos e adotando para si o personagem de Rita Hayworth, sua decadência física já tinha começado, ainda que ela se rejuvenescesse em encontros furtivos como o que aconteceu naquele feriado de Páscoa. 0 final do conto aponta para essa finitude, indicando a morte como um destino certo, um fim para o erotismo vivido pela Adelina-Gilda: "Só pensou em jogá-los fora quando as varizes começaram a engrossar, escalando as coxas"(ABREU, 1988, p.80).

Em "Os Sapatinhos Vermelhos", Caio Fernando Abreu se utiliza de diversas referências aos contos de fadas, mas o sentido de seu conto é completamente oposto ao objetivo principal desses textos para crianças: o conto não tem um final feliz e redentor, ao contrário. Apesar da magia dos sapatos vermelhos indicar certo rejuvenescimento de Adelina, ela não se transforma por completo em uma Gilda sedutora, mas permanece sendo a mulher de meia-idade, comportada, com os "cabelos presos, vestida de marrom, gola fechada".

Se Adelina utiliza da vingança como forma de superar o abandono e para isso escolhe para se envolver homens que são completamente diferentes do ex-amante, a escolha dos novos objetos de desejo do narrador de "Sem Ana, Blues", embora seja feita pelo mesmo critério, apresenta um objetivo aparentemente diferente: aqui, a meta parece ser a autopunição, como se os novos relacionamentos matassem Ana dentro de si, o que ele parece não desejar:

comecei a trazer outras mulheres para casa. Mulheres que não eram Ana, mulheres que não tinham nem teriam nada a ver com Ana. Se Ana tinha os seios pequenos e duros, eu as escolhia pelos seios grandes e moles, se Ana tinha os cabelos quase louros, eu as trazia de cabelos retos, se Ana tinha a voz rouca, eu as escolhia pelas vozes estridentes que gemiam coisas vulgares quando estávamos trepando, bem diversas das que Ana dizia ou não dizia, ela nunca dizia nada além de amor-amor ou meu-meninoquerido (ABREU, 1988, p.44).

Apesar da tentativa de se desprender da antiga namorada, essas relações geram um intenso sofrimento e ele acaba por "choramingar" a perda de Ana com essas mulheres:

Eu acho que já vim aqui alguma vez, alguma dizia, e eu falava não lembro, pode ser, esperando que tirasse a roupa enquanto eu bebia um pouco mais para tentar entrar nela, mas meu pau quase nunca obedecia, então eu afundava a cabeça nos seus peitos e choramingava babando sabe, depois que Ana me deixou eu nunca mais, e mesmo quando meu pau finalmente obedecia, depois que eu conseguia gozar seco ardido dentro dela, me enxugar com alguma toalha e expulsá-la com um cheque cinco estrelas, sem cruzar - então eu me jogava de bruços na cama e pedia perdão a Ana por traí-la assim, com aquelas vagabundas. Trair Ana, que me abandonara, doía mais que ela ter me abandonado, sem se importar que eu naufragasse toda noite no enorme corredor de transatlântico daquele apartamento em plena tempestade, sem salva-vidas (ABREU, 1988, p.45, grifo meu). 
Não é apenas assim que o narrador tenta se punir. Ele relata cinco fases do processo de superação, grande parte delas marcadas por ações autodestrutivas. A primeira consistia em um silenciamento, em uma imobilidade completa, segurando nas mãos o bilhete em que Ana rompia o relacionamento. Segue-se a isso, um período de intensas bebedeiras, em que ele sentia apenas três gostos na boca, "de vodka, de lágrima e de café" (ABREU, 1988, p.43). Essa fase acaba quando ele "decide matar Ana dentro de tudo aquilo que era eu" (ABREU, 1988, p.44) e passa a se relacionar sexualmente com outras mulheres, embora em grande parte das vezes não conseguisse ter ereção ou chorasse após o ato sexual, se sentindo culpado por trair Ana, como pode ser visto no trecho anteriormente citado.

Em "Luto e melancolia", Freud (2002) identifica similaridades entre o processo do luto e o da melancolia. Em ambos os casos, perdem-se o objeto de amor e inicia-se um longo processo rumo à superação desse trauma. A diferença é que na melancolia a pessoa "sabe quem perdeu, mas não o que perdeu nesse alguém". Além disso, se no luto é "o mundo que se torna pobre e vazio; na melancolia, é o próprio ego". Aparentemente porque a escolha do objeto fez-se de forma narcísica, de modo que o ego sente-se esvaziado após a separação.

Freud destaca uma série de sintomas típicos da melancolia que podem ser identificados nessa personagem: a insônia, a recusa em se alimentar e a falta de preocupação com a própria aparência física e saúde. Evidentemente, não se trata aqui de diagnosticar o personagem, mas analisar com mais precisão a diferença entre o comportamento do narrador de "Sem Ana, Blues" e o de Adelina em "Os Sapatinhos Vermelhos" ao lidar com a separação, tendo em vista os conceitos de luto e de melancolia apresentados por Freud.

O principal ponto a ser destacado é como a atitude autodestrutiva desse personagem apresenta alguns pontos em comum com o modo como Adelina supera o abandono. Em primeiro lugar, evidentemente, ambas as reações são formas de superar a separação. Mas mais do que isso, é preciso destacar como também em "Sem Ana, Blues", o modo de fazer isso é através da vingança, apesar da aparente devoção que o personagem afirma ter em relação àquela que o abandonou.

Em "Os Sapatinhos Vermelhos", isso é indiscutível, pois a própria personagem reconhece-se plenamente satisfeita apenas quando rejeita o ex-amante após a orgia com os três "machos vindos das ruas". Em "Sem Ana, Blues", no entanto, embora a auto-agressão a que a personagem se submete, aparentemente, indique uma total devoção a Ana e uma recusa em agredi-la ou abandoná-la, indiretamente ele se vinga da mulher que o abandonou.

Freud explica esse processo ao analisar a melancolia:

Se o amor pelo objeto - um amor que não pode ser renunciado, embora o próprio objeto o seja - se refugiar na identificação narcisista, então o ódio entra em ação nesse objeto substitutivo, dele abusando, degradando-o, fazendo-o sofrer e tirando satisfação sádica de seu sofrimento. A autotortura na melancolia, sem dúvida agradável, significa, do mesmo modo que o fenômeno correspondente na neurose obsessiva, uma satisfação das tendências do sadismo e do ódio relacionadas a um objeto, que retornaram ao próprio eu do indivíduo (FREUD, 2002, p.256). 
Ao beber em excesso, alimentar-se mal, relacionar-se com mulheres que não deseja, a personagem não age de forma autodestrutiva, mas pune seu objeto de desejo que, nessa escolha narcísica, confundiu-se com ele. Para Freud, "os pacientes ainda conseguem, pelo caminho indireto da autopunição, vingar-se do objeto original e torturar o ente amado através de sua doença, à qual recorrem a fim de evitar a necessidade de expressar sua hostilidade para com ele" (FREUD, 2002, p.257).

Ainda que de forma menos explícita do que faz Adelina, o mecanismo aqui parece ser o mesmo: vingar-se de quem o abandonou para, com isso, matar o objeto de amor dentro de si. Ambas as vinganças são bem sucedidas, embora, isso não colabore para que o processo de superação se complete. Se a morte e a decrepitude física espreitam o futuro de Adelina, ao narrador de "Sem Ana, Blues" cabe uma permanente sensação de abandono: "Que Ana me deixou, que não vai voltar nunca, que é inútil tentar encontrá-la e finalmente, por mais que eu me debata, que isso é para sempre" (ABREU, 1988, p.47).

No final do conto, a personagem se vê capaz de trabalhar, se relacionar com outras pessoas e viver uma vida normal sem a presença de Ana. Embora isso pareça indicar uma superação, ela não é absoluta, como se vê. Sua condição é irrevogável, ainda que ele procure auxílio espiritual e psicológico no esoterismo, na religião e nas terapias de grupo durante o "ciclo da anunciação". Ou que procure uma nova aparência e novos relacionamentos, na quarta e última fase descrita por ele:

e fui ficando tão bonito e renovado e superado e liberado e esquecido dos tempos em que Ana ainda não tinha me deixado que permiti, então que viesse também o ciclo dos fins de semana em Búzios, Guarujá ou Monte Verde e de repente quem sabe Carla, mulher do Vicente, tão compreensível \& madura, e inesperadamente Mariana, irmã do Vicente, tão disponível \& natural em seu fio dental metálico e, por que não, afinal, o próprio Vicente, tão solícito na maneira como colocava pedras de gelo no meu escocês ou batia uma generosa carreira sobre a ágata (ABREU, 1988, p.46).

Embora aparentemente muito tenha mudado após o momento em que Ana o deixou, ele ainda sente como se nada tivesse mudado, como se ele ainda se encontrasse naquele mesmo momento. Seu equilíbrio é frágil, como ele afirma na bonita imagem que encerra o conto:

E para sempre, então, agora, me sinto como uma bolha opaca de sabão, suspensa ali no centro da sala do apartamento, à espera de que entre um vento súbito pela janela aberta para levá-la dali, essa bolha estúpida, ou que alguém espete nela um alfinete, para que de repente estoure nesse ar azulado que mais parece o interior de um aquário, e desapareça sem deixar marcas. (ABREU, 1988, p.47).

Como em outros contos do livro, embora haja sofrimento na conflituosa relação das personagens com o desejo, é esse conflito que as mantém vivas, visto que, estourar essa "bolha opaca de sabão" que ele se tornou significaria sua aniquilação e morte.

No conto que intitula o volume, há uma definição precisa da concepção de erotismo adotada por Abreu nesse livro cuja temática principal é a sexualidade. Abandonado por um dragão invisível por quem se apaixonou, o narrador de "Os dragões não conhecem o paraíso" se dá conta de que esse abandono é fundamental para a 
felicidade desse ser mítico, clara metáfora das relações amorosas. É preciso reconhecer que é no conflito que o dragão - e a sexualidade - se realizam:

Os dragões não querem ser aceitos. Eles fogem do paraíso, esse paraíso que nós, as pessoas banais, inventamos [...]. Os dragões não conhecem o paraíso, onde tudo acontece perfeito e nada dói nem cintila ou ofega, numa eterna monotonia de pacífica falsidade. Seu paraíso é o conflito, nunca a harmonia (ABREU, 1988, p.155, grifo meu).

O conflito entre vida e morte, criação e destruição, Eros e Thanatos, constitui o amor e o desejo, na concepção apresentada no livro de Caio Fernando Abreu. O mesmo defende Bataille (2004), em O Erotismo. Para o autor, o erotismo é a maneira encontrada pelo homem para tentar superar a descontinuidade intrínseca a um ser cujo nascimento traz em si o caráter da destruição. Isso porque para que a reprodução sexuada ocorra, é preciso que um ser deixe de existir, se divida e se transforme em dois ou mais seres. Assim, o "novo ser é ele próprio descontínuo, mas ele traz em si a passagem à continuidade, a fusão, mortal para cada um deles, dos dois seres distintos" (BATAILLE, 2004, p.24).

Essa descontinuidade marca, para Bataille, a constituição do ser humano. Ainda que o fim último da relação sexual não seja a reprodução, ela sempre carrega em si esse sentido, próprio do homem, próprio do erotismo: "Somos seres descontínuos, indivíduos que morrem isoladamente em uma aventura inteligível, mas temos a nostalgia da continuidade perdida" (BATAILLE, 2004, p.24). Para o autor, "o campo do erotismo é o campo da violência, o campo da violação". É preciso romper de forma violenta com o ser constituído para que a passagem da descontinuidade para a continuidade ocorra e a vida e a sexualidade - se perpetue.

O erotismo contém em sua origem a destruição e o conflito, ao mesmo tempo em que é uma maneira de tentar superar essa descontinuidade que constitui o ser humano. Isso porque, segundo ele, "[n]a base, a paixão dos amantes prolonga, no campo da simpatia moral, a fusão dos corpos entre eles" (BATAILLE, 2004, p.32). Fundidos os corpos, a solidão intrínseca a esse homem descontínuo parece se dissipar e é isso que buscam os amantes. Mas não é possível prolongar essa fusão infinitamente. Assim, aquele que acreditar nessa ilusão não encontra a felicidade absoluta, pois o próprio funcionamento das paixões traz em si uma alta carga de sofrimento:

Sua essência [da paixão amorosa] é a substituição da persistente descontinuidade de dois seres por uma continuidade maravilhosa entre dois seres. Mas essa continuidade é sobretudo sensível na angústia, na medida em que ela é inacessível, na medida em que ela é a busca na impotência e no tremor [...]. Pois, para os amantes, existe mais chance de não poder se encontrar por muito tempo que de gozar de uma contemplação desvairada da continuidade intima que os une (BATAILLE, 2004, p.33, grifo meu).

Para Khel (1990), o conflito é o principal elemento constituinte do desejo. Assim a autora expõe o objetivo de seu artigo:

O que pretendo investigar aqui é alguma coisa a respeito dessa fome de mundo, que, quando se nos apresenta desinterditada, é capaz de nos proporcionar experiências muito próximas da felicidade - ainda que 
frequentemente acompanhadas da chamada angústia de prazer. E notem que estou relacionando a felicidade ao sentir fome, não ao sentir saciedade; ainda que eu admita que uma parte, mas só uma parte, da felicidade da fome venha da antecipação da experiência da saciedade, não posso admitir que essa antecipação seja responsável por toda a alegria da fome, já que também sabemos por experiência que a saciedade está mais próxima do tédio, de uma certa tristeza, de uma espécie de morte do desejo, do que da fome - e, portanto, a saciedade é sempre também uma decepção (KHEL, 1990, p.366).

Embora a desilusão seja marcante no modo como o amor é apresentado nos contos, é impossível não notar que esses eventos constituem uma espécie de realização, o que possibilita a manutenção da tensão constitutiva do desejo. Não ocorre aqui um retrato daquilo que Khel chama de "psicose da miséria". Ainda que desiludidas, as personagens são capazes de desejar. Isso porque a

alegria de desejar depende de uma certa dose de confiança no real, uma certa quantidade de experiências de gratificação que permitam esperar que esse lugar externo ao psiquismo para onde se espraia a "fome do mundo" seja um lugar de onde pode vir alguma espécie de confirmação, de aplacamento, pelo menos temporário, de minhas indagações [...]. Quando o real é hostil, lugar de privação e frustração permanentes, tudo isso muda, e nos deparamos com a ameaça constante de afrouxamento dos vínculos e dos investimentos do Eu em relação à realidade: é o que se pode chamar de psicose da miséria (KHEL, 1990, p.366).

Por um lado, as personagens desses contos vivenciam algumas experiências de gratificação: o namoro com Ana, em "Sem Ana, blues" e a orgia com três desconhecidos em "Os Sapatinhos Vermelhos" aplacam temporariamente a "fome do mundo" das personagens, permitindo que o desejo não seja completamente frustrado, afrouxando os vínculos do Eu em relação à realidade, tal como Khel determina que aconteceria na psicose da miséria. No entanto, essa satisfação não é plena, pois o princípio da realidade se impõe e as personagens são abandonadas.

É a tensão entre as pequenas realizações do desejo e as constantes frustrações que garante não apenas a permanência do desejo, mas a existência desses sujeitos. Assim, embora os dragões e os amantes se frustrem por não conhecerem o paraíso, é esse fato que os mantém vivos e desejando. Atingir esse paraíso "onde tudo acontece perfeito e nada dói nem cintila ou ofega, numa eterna monotonia de pacífica falsidade" significaria a morte dos conflitos que possibilitam o desejo e, portanto, a própria morte desses personagens enquanto sujeitos desejantes. É o conflito entre as pulsões de vida e as pulsões de morte que determina não apenas a existência do desejo, mas a própria existência do homem.

\section{REFERÊNCIAS BIBLIOGRÁFICAS}

ABREU, C. F. Os Dragões não conhecem o Paraíso, São Paulo: Companhia das Letras, $1988 .$.

BATAILLE, George. O Erotismo. São Paulo: Arx, 2004. 
BETTELHEIM, B. A psicanálise dos contos de fadas, Rio de Janeiro: Paz e Terra, 1980.

CALLEGARI, J. Caio Fernando Abreu: inventário do escritor irremediável, São Paulo: Seoman, 2008.

CARUSO, I. A Separação dos Amantes: uma fenomenologia da morte, São Paulo: Diadorim Cortez, 1989.

CHAUÍ, M. Repressão sexual: essa nossa (des)conhecida, São Paulo: Editora Brasiliense, 1984.

FREUD, S. "Luto e melancolia", In: Obras completas. Rio de Janeiro: Imago, 2002, vol. XVII.

KHEL, M. "O desejo da realidade". In: NOVAES, A. (org). O Desejo. Rio de Janeiro: Companhia das Letras/Funarte, 1990.

KLEIN, M. "O luto e suas relações com os estados maníaco-depressivos", In: Amor, culpa e reparação. Rio de Janeiro: Imago Editora, 1996.

RECANTO DAS LETRAS (sítio). http://recantodasletras.uol.com.br/contosdefantasia/ 697486. Acesso em Janeiro de 2009.

Artigo recebido em: 15/07/09

Artigo aprovado em: 03/09/09

Referência eletrônica: SOUZA, Thais Torres de. "A Paixão dos Amantes: Separação e Superação em "Os Sapatinhos Vermelhos" e "Sem Ana, BLues", de Caio Fernando Abreu", Revista Criação \& Crítica (online), n. 3, p.02-16, 2009. 